\title{
Types of Interjection \\ (A Descriptive Analysis in Dragon Ball Super English Comic Book)
}

\author{
Willyana Ramlan, Yana Putra Triana, Ferany Shaily Maulida \\ English Education Program, STKIP Subang \\ Subang, Indonesia \\ E-mail: willyanaramlan25@gmail.com, yanaputratriana@gmail.com, \\ raffasya.2017@gmail.com
}

\begin{abstract}
The aims of the study are to describe the types and function of the interjection contained in the comic "Dragon Ball Super Vol.04" by Akira Toriyama. The subject of this research is Dragon Ball Super comic. The object of this research is all the words, phrases and sentences which are interjection in the comic Dragon Ball Super. This study used descriptive qualitative method. The result shows 7 types of interjection contained: Interjection of confused, interjection of approval, interjection of sadness, interjection of anger, interjection of happiness, interjection of attention, and interjection of disgust.
\end{abstract}

Keywords: Comic, Dragon Ball, Functions, Interjection Types

\section{INTRODUCTION}

One of popular communication media is comic. Comic is defined as moving images arranged in such a way as to form the fabric of the story. It is usually in the form of illustrated stories found in magazines, newspapers, or in the form of books. Comics have is an oral language, namely a language that expresses the expressions and feelings of the speakers themselves and the opponents of speech. According to Grevisse (1980) the expression of expression itself is often known as interjection which functions as a marker or as an expression of speaker's feelings.

Interjection can be conveyed to the other person in spoken and written form. It is used to express some feelings and emotions of someone in handling or expressing the feeling that cannot be expressed easily in common sentences because interjection used to give a different meaning in various situations or actions (Dubois, 2001). Written forms of interjection can be found in novels, poems and comics. "It is perhaps true that apart from nouns and verbs, interjections-those little words, or 'non-words', which can constitute utterances by themselves - are another word class found in all languages" (Ameka, 1992, p. 101). One example of comic as written form is Dragon Ball. It contains interjections to make every event in the comic live. Without interjection, the conversation in the comic 
will feel flat because in interjection there is a representation of the expression or mood of the speaker.

There are some studies and articles about interjection that related to the research. The first one is Interjection in English Comic Book "Scooby-Doo Where Are You" (Anggoro, 2013). This research found 20 types interjection words based on their function which are divided into four (emotive, conative, cognitive, and phatic). Another research which studied Interjection in Comics "Les Schtroumpes" by Peyo conducted by Palumian (2014) showed there are 5 types of interjection whose functions are emotive function, phatic function, and conative function.

This study is similar to the previous studies but uses different data source. The data for the study were taken from "Dragon Ball Super Vol.04" by Akira Toriyama. Therefore, the aims of the study are to describe the types and function of the interjection contained in the comic.

\section{LITERATURE REVIEW}

According to Ameka (1992), interjections are little words or nonwords which can stand on its own and have their own word class found in any languages. The word interjection comes from the Latin interjicere "to throw between," as they were seen as words that were tossed into a sentence, without being syntactically related to other items. Examples of English interjections are $o h !, a h !, u g h !$, and $o u c h$ ! Interjections such as these, which have only an interjectional function. Ameka also states that interjections are relatively conventionalized vocal gestures (or more generally linguistics gestures) which express a speaker's mental state, action or attitude or reaction to a situation (Ameka, 1992, p. 105).

Interjection is divided into following types on the basis of way to express interjections in the sentence such as joy, surprise, approval, sorrow, attention, etc. (Singh, 2019). There are some types of interjection that express the speaker's feelings. (1) Interjection of happiness, this type of interjection is used in the sentence to indicate immediate joy and happiness on any happy occasion occurred such as hooray, yippie, yahoo, etc. (2) Interjection of satisfied or approval, this type of interjection is used in the sentence to express the strong sense approval or agreement for something that has 
happened such as well done, bravo, brilliant, etc. (3) Interjection of attention or command, this type of interjection is used in the sentence to draw attention of someone such as look, behold, listen, etc. (4) Interjection of confused or surprised, this type of interjection is used in the sentence to express the strong sense of surprise or confused about something that has happened such as what, seriously, really, etc. (5) Interjection of sadness or hurt, this type of interjection is used in the sentence to express the emotion of sadness or hurt about something unfortunate has happened such as ouch, sorry, aww, etc. (6) Interjection of disgust, this type of interjection is used in the sentence to express the emotion or expression about disgust such as eww, gross, yuck, etc. (7) Interjection of anger or denial, this type of interjection is used in the sentence to express the emotion or expression about anger or madness such as damn!, how dare you!, etc.

According to Ameka (1992, pp. 113-114), interjections can be classified into three functions there are emotive function, conative function and phatic function. Emotive function is those that express the speaker's state with respect to the emotions and sensations they have at the time. For example, as quoted by Ameka in Anggoro (2013, p. 4) Yuk! 'I feel disgust', Wow! 'I am surprised', Ouch! 'I feel pain' etc. Conative function is those expressions which are directed at an auditor. They are either aimed at getting someone's attention or they demand on action or response from someone of a speaker's wants. For example, sh! 'I want silence here', eh? 'I want to know something' (Anggoro, 2013, p. 4). Phatic function is used in the establishment and maintenance of communicative contact. A variety of conventional vocalizations, which express a speaker's mental attitude towards the ongoing discourse, that is back channeling or feedback signaling vocalizations, may be classified as phatic. For example, $m h m, u h-u h$, yeah (Anggoro, 2013, p. 5).

According to Moeliono as cited in Palumian (2014, p. 7) Comics are illustrated stories (in magazines, newspapers or in the form of books) which are generally easy to understand and funny. According to Scott Mc Cloud in his book entitled Understanding Comics as cited in Palumian (2014, p. 7), comics are pictures and other symbols that are fixed in a certain order, aiming to provide information and or to achieve aesthetic responses from readers. 


\section{METHOD}

The method that used in this research was qualitative method with descriptive analysis. The data source of this research was Dragon Ball Super Vol.04. There are some stages conducted in analyzing the data. First, all the interjections were collected from the comic. Then, all the collected interjections were classified based on the types and the functions. After that, the classified data were analyzed the answer the research questions. Finally, conclusion was driven.

\section{RESULT AND DISCUSSION}

This part consists of the result and the explanation of the answer to research question. In this study they were divided into 7 types of interjection. The researcherss found the number of words each types of interjection and classified it into the table.

Table 1. Number of Words for Types of Interjection

\begin{tabular}{|c|c|c|}
\hline No & Types of Interjection & Number of Words \\
\hline 1 & Interjection of surprised & 7 \\
\hline 2 & Interjection of approval & 34 \\
\hline 3 & Interjection of sadness & 16 \\
\hline 4 & Interjection of anger & 15 \\
\hline 5 & Interjection of happiness & 14 \\
\hline 6 & Interjection of attention & 1 \\
\hline 7 & Interjection of disgust & 14 \\
\hline
\end{tabular}

\section{Interjection of surprised}

The first one is 25 words for interjection of surprised type. Most of the words included in this type is because the context of the speakers is always confused with the situation that they face and also the speakers are surprised by things that they did not expect. For example, "Bulma is confused because Trunks are not on the Capsule Corp. 
Plane and what appears is a cat" (Page 9) and "Kaio was surprised that Goku's technique worked" (Page 83).

\section{Interjection of approval}

There are 7 words for interjection of approval type. Most of the words included in this type is because the context of the speakers is grateful with the situation that they face or something that they got and also the speakers are agrees or praises to something or respond to the request. For example, "Whis agreed with Beerus not to go into the future (Page 13)". And "Goku accepts request from Future Trunks to defeat Fused Zamas (Page $173) "$

\section{Interjection of sadness}

In this study, the researchers found 34 words for interjection of sadness type. Most of the words included in this type is because the context of the speakers is sad with the situation that they face and also the speakers are hurt or exhausted. For example, "Whis was sad after hearing Bulma's statement" (Page 12) and "Future Trunks screaming in pain after being hit by Goku Black” (Page 17).

\section{Interjection of anger}

There are 16 words for interjection of anger. Most of the words included in this type is because the context of the speakers is angry with someone or shouted to unleash the power and also the speakers are rejecting something or not accepting the situation. For example "Vegeta is upset because Goku want to know what he wants to do" (Page 14); "Goku unleash his power to learn Mafuba technique" (Page 51) and "Zamas was angry because he could be defeated by Goku and Vegeta" (Page 92).

\section{Interjection of happiness}

The researchers found 15 words for interjection of happiness. Most of the words included in this type is because the context of the speakers is happy because they got something and also the speakers managed or success to do something. For example, "Goku success to learn the new technique" (Page 51) and "Goku is happy that his attack can hit Fused Zamas" (Page 183). 


\section{Interjection of attention}

There are 14 words for interjection of attention. Most of the words belong to this type, because the context is which the speakers calling or distracting someone and also the speakers are giving orders to take someone attention. For example, "Goku meets Future Mai and he greets her" (Page 62) and "Future Trunks warns the others to stay away from Fused Zamas attack” (Page 112).

\section{Interjection of disgust}

Researchers just found 1 word for interjection of disgust. In this case the word that included to this type is because the context is the speaker feel disgusted to someone. For example, "Fused Zamas felt disgusted by the power of Vegeta which was very weak" (Page 174).

\section{DISCUSSION}

In this present study, the results are related to other studies. However, there are several differences found in this study.

The result of the research conducted by Palumian (2014) showed that the form of interjection in Peyo's Les Schtroumpfs comic was classified into 5 types, they are interjection of happiness, sadness, anger, attention, and satisfied. On the other hand, this study found 7 types of interjection. They are interjection of surprised, approval, sadness, anger, happiness, attention, and disgust.

In addition, Anggoro (2013) who studied the Interjection in English Comic Book "Scooby-Doo Where Are You" found 20 types interjection words. But based on their function, the interjections are only four types (emotive, conative, cognitive, and phatic).

\section{CONCLUSION}

Research on interjection contained in Dragon Ball Super Vol.04 English comic book produces the following conclusions. There are 7 types of interjection contained in this comic. They are interjection of surprised, interjection of approval, interjection of 
sadness, interjection of anger, interjection of happiness, interjection of attention, and interjection of disgust.

Whereas based on the function, it is found that there are three kinds of interjection functions. They are self-expression, giving orders, and back channeling or respond the question. The types of interjection are depending from the expressions of the speakers, because one-word interjection has different types even though this interjection word has the same form.

\section{REFERENCES}

Ameka, F. (1992). Interjections: The universal yet neglected part of speech. Journal of Pragmatics, 101-118. Retrieved August 8, 2019, from https://www.sciencedirect.com/science/article/abs/pii/037821669290048G

Ameka, F. (1992). Interjections: The universal yet neglected part of speech. Journal of Pragmatics, 101-118. Retrieved August 8, 2019, from https://www.sciencedirect.com/science/article/abs/pii/037821669290048G

Anggoro, Y. W. (2013). INTERJECTION IN ENGLISH COMIC BOOKS "SCOOBYDOO WHERE ARE YOU". Universitas Nasional, English Departement. Jakarta: Universitas Nasional Jakarta. Retrieved August 5, 2019, from http://journal.unas.ac.id

Dubois, J. (2001). Dictionnaire de Linquistique. Paris: Larousse.

Grevisse, M. (1980). Le Bon Usage. Paris: Gembloux Duculot.

Palumian, A. C. (2014). INTERJEKSI DALAM KOMIK “LES SCHTROUMPFS” KARYA PEYO. Yogyakarta. Retrieved August 8, 2019, from https://eprints.uny.ac.id/20070/

Palumian, A. C. (2014). INTERJEKSI DALAM KOMIK “LES SCHTROUMPFS” KARYA $P E Y O$. Universitas Negeri Yogyakarta, Fakultas Bahasa dan Seni, Yogyakarta. Retrieved August 8, 2019, from https://eprints.uny.ac.id/20070/

Singh, A. (2019, June 11). INTERJECTION. Retrieved August 4, 2019, from TeachingBanyan.com: https://www.teachingbanyan.com/grammar/interjection/

Toriyama, A. (2015). Dragon Ball Super Vol.04. (M. First, Ed., \& S. Inc., Trans.) Tokyo: SHUEISA Inc. 